\title{
Gastro-oesophageal reflux disease and Helicobacter pylori: an intricate relation
}

\author{
D McNamara, C O’Morain
}

\begin{abstract}
Summary
Heartburn is a common symptom affecting $21-44 \%$ of the adult population on a monthly basis. Oesophagitis is less common, affecting $2 \%$ of individuals.

Epidemiological studies have shown that patients with gastro-oesophageal reflux disease (GORD) have similar incidence rates of Helicobacter pylori infection as do controls. Some groups have reported that there is a lower incidence, deducing that infection does not cause, and in some way confers protection against GORD. Additional supportive evidence is available from reports of GORD development following successful $H$ pylori eradication. The mechanisms involved are complicated. Individuals with $H$ pylori induced pangastritis and subsequent hypochlorhydria may be protected whereas those with an antral predominant gastritis, as in duodenal ulcer disease, with an increased acid output may be prone to development of GORD.

Recent evidence has linked $H$ pylori infection with the development of inflammation of the gastric cardia-carditis. Reports are available which show that carditis is a frequent finding in patients with GORD. The incidence of both cardia and oesophageal carcinoma is increasing. The relation between GORD, carditis, intestinal metaplasia, and cardia carcinoma is unclear. Intestinal metaplasia may result from multifocal atrophic gastritis, linked to $H$ pylori infection or from GORD and the development of Barrett's oesophagus. Long term follow up studies will be required to assess the malignant potential of these histological entities and whether or not $H$ pylori infection has an aetiological role.
\end{abstract}

\section{Introduction}

Gastro-oesophageal reflux disease refers to the abnormal exposure of the oesophageal mucosa to gastric contents, resulting in a spectrum of conditions. Symptoms of heartburn or acid regurgitation affect $21-44 \%$ of the adult population on a monthly basis. ${ }^{1-3}$ Oesophagitis is less prevalent, and is reported to occur in up to $2 \%$ of individuals. ${ }^{4}$ Symptoms have been shown to have a specificity of $85-95 \%$ and sensitivity of $6-39 \% .^{6}$ Patients with GORD frequently present with atypical symptoms; up to $50 \%$ of endoscopically diagnosed cases of oesophagitis present with symptoms other than heartburn or acid regurgitation. ${ }^{7-9}$ In addition GORD is the underlying diagnosis in $2-15 \%$ of subjects undergoing investigation for dyspepsia. Accurate diagnosis of GORD can be difficult with currently accepted criteria including symptoms of heartburn and/or acid regurgitation, improvement with proton pump inhibitor (PPI) treatment, 24 hour oesophageal $\mathrm{pH}$ assessment, and/or histological evidence of oesophagitis. Long term sequelae include benign strictures, Barrett's oesophagus, and adenocarcinoma.

Pathophysiological mechanisms described include abnormal transient relaxation of the lower oesophageal sphincter (TLOSR), ${ }^{10-14}$ impaired oesophageal motility, ${ }^{15}$ delayed gastric emptying, ${ }^{16}{ }^{17}$ impaired mucosal defences, ${ }^{18}{ }^{19}$ toxic nature of refluxed material (acid, bile), ${ }^{20-24}$ and the presence of hiatus hernia. Although it would appear that GORD is a multifactorial condition predominantly related to abnormal upper gastrointestinal motility, recent interest has focused on the relation between Helicobacter pylori infection and GORD.

\section{$H$ pylori and the aetiology of GORD}

$H$ pylori is a common infection, responsible for a variety of gastroduodenal pathology, duodenal and gastric ulcer, mucosa associated lymphoid tissue (MALT) lymphoma, and gastric carcinoma. The effects of $H$ pylori infection on the pathophysiological mechanisms involved in the aetiology of GORD have been examined. $H$ pylori infection has been shown to produce an increase in basal and stimulated gastric acid output through a number of mechanisms, including gastrin, somatostatin, and inflammatory mediators, and this phenomenon of increased acid output has been shown to occur in asymptomatic cases as well as those with peptic ulcer disease and nonulcer dyspepsia. ${ }^{25-32}$ Increased acid secretion as a result of $H$ pylori infection is a plausible aetiological mechanism of GORD in a subset of cases, supported by the observation that patients with duodenal ulceration are more likely to suffer from reflux oesophagitis. ${ }^{33}$ However, $H$ pylori colonisation of the gastric mucosa may result in hypochlorhydria as seen in individuals with a diffuse gastritis and gastric atrophy. ${ }^{34}$ Patients with this pattern of disease seem to be at less risk of developing GORD than controls. ${ }^{35}{ }^{36}$ There is evidence to associate $H$ pylori infection with both the development of hypochlorhydria and increased acid secretion, depending on the inflammatory response induced. As a result, the effect of $H$ pylori infection on the development of GORD is similarly contradictory.

Abbreviations used in this paper: GORD, gastro-oesophageal reflux disease; TLOSR, transient relaxation of the lower oesophageal sphincter; MALT, mucosa associated lymphoid tissue; PPI, proton pump inhibitor. 
Table 1 Epidemiological studies investigating the role of Helicobacter pylori infection in gastro-oesophageal reflux disease (GORD)

Prevalence of $H$ pylori in GORD

Similar to controls

O'Connor and Cunnane ${ }^{4}$

Borkent and Beker ${ }^{46}$

Walker and colleagues ${ }^{47}$

Cheng and colleagues ${ }^{48}$

Newton and colleagues ${ }^{49}$

Befrits and colleagues ${ }^{50}$

Decreased

Liston and colleagues ${ }^{51}$

Werdmuller and Loffeld ${ }^{52}$

Vicari and colleagues ${ }^{5}$

Ohara and colleagues ${ }^{35}$

Haruma and colleagues ${ }^{54}$

Severity of GORD and H pylori

Similar to controls

O'Connor and Cunnane ${ }^{45}$

Newton and colleagues ${ }^{49}$

Increased

Werdmuller and Loffeld ${ }^{52}$

Decreased

Cargill and colleagues ${ }^{57}$

Grebenev $^{56}$

Sehiguchi and colleagues ${ }^{55}$

Delayed gastric emptying has been reported in association with GORD development. Results of studies exploring the effect of $H$ pylori on gastric emptying are variable. Several groups have reported no difference between $H$ pylori positive and negative subjects. ${ }^{37-39}$ Other groups have shown abnormal antroduodenal motility in patients with GORD and $H$ pylori and delayed gastric emptying in patients with antral predominant gastritis, with or without $H$ pylori infection. ${ }^{40-42}$ There is no clear evidence to associate $H$ pylori infection with a definite dysfunction of gastric emptying and it is unlikely to be a major aetiological factor linking $H$ pylori and GORD.

It has been postulated that $H$ pylori colonisation of the gastric cardia may result, through inflammatory mediators and vagal stimulation, in increased TLOSR episodes, hence increasing the likelihood of GORD development. ${ }^{42-44}$ Several groups are investigating the role of carditis with respect to GORD but as yet there is no clear evidence to support this hypothesis.

\section{Epidemiology}

Epidemiological studies have in general found little or no association between $H$ pylori infection and GORD (table 1), similar infection rates being reported in patients with GORD and in controls. ${ }^{45-51}$ Some groups have reported a lower incidence of $H$ pylori infection in individuals with GORD and have surmised that infection in some way reduces an individual's risk of reflux oesophagitis. ${ }^{35}{ }^{52-54}$ The observation that $H$ pylori infection was negatively associated with the severity of oesophagitis has added weight to the theory of a protective role for $H$ pylori in GORD. ${ }^{55}$ However, there is evidence to the contrary. ${ }^{57}$

More recently the nature of the infecting organism has been examined. To date three groups have shown that $\operatorname{cag} A$ positive infecting strains reduce the risk of both GORD and its complications, including Barrett's oesophagus and oesophageal and cardia carcinoma..$^{5359}$ Infection with $\operatorname{cag} A$ positive strains of $H$ pylori is associated with a more severe mucosal inflammation in the corpus and antrum, potentiating the risk of developing gastric atrophy and achlorhydria. ${ }^{60-62}$

Such mechanisms have been suggested to explain the negative association between $\operatorname{cag} A$ positive strains and GORD. In addition an increased density of infection, associated with virulent infecting strains, may result in an increased production of ammonia, thus potentiating the effects of PPIs. ${ }^{63}$ The fact that virulent strains are responsible for $80-100 \%$ of duodenal ulcers and are associated with an increase in acid production seems contradictory. ${ }^{64}$ Yet it is known that a history of peptic ulcer is associated with a reduced risk of proximal and distal gastric cancers. ${ }^{65}$ With regard to Barrett's oesophagus the majority of studies have again found no association with $H$ pylori. ${ }^{66}{ }^{67}$ Henihan et al have shown a positive correlation between the severity of chronic inflammation in Barrett's oesophagus and $H$ pylori. The possible mechanisms underlying this observation are unknown. ${ }^{68}$

\section{Carditis, $H$ pylori, and GORD}

The gastric cardia is the most proximal portion of the stomach, occupying a small zone just distal to the oesophagogastric junction. Under normal circumstances, it comprises tightly packed mucus secreting cells and is devoid of inflammatory cells. Recent interest has focused on carditis, as a possible marker or consequence of GORD or as a possible extension of $H$ pylori induced pangastritis.

Carditis has been reported to be a sensitive marker of GORD. Oberg et al have revealed a positive association between carditis and GORD, as determined by a 24 hour ambulatory $\mathrm{pH}$ oesophageal probe assessment. ${ }^{69}$ This study did not examine the role of $H$ pylori infection. Others disagree, and have reported that carditis is a manifestation of extensive $H$ pylori colonisation and is independent of oesophagitis. ${ }^{70-72}$

The incidence of proximal gastric cancers like that of oesophageal adenocarcinoma is increasing, ${ }^{73}$ whereas that of $H$ pylori infection and distal gastric cancer is falling. Barrett's oesophagus, a consequence of GORD, is a risk factor for the development of oesophageal adenocarcinoma with known premalignant histological markers including intestinal metaplasia and dysplasia. Intestinal metaplasia of the cardia may similarly be a marker of malignant potential though it is not known whether it arises as a long term consequence of GORD or as a result of $H$ pylori infection and associated pangastritis. Consideration of the malignant potential of intestinal metaplasia at the cardia is warranted as it has been identified in proximity to adenocarcinomas of this region. ${ }^{74}$ Surprisingly intestinal metaplasia of the cardia has been reported in 5-23\% of subjects undergoing routine endoscopy and was found more frequently in controls than in those with either oesophagitis or Barrett's oesophagus. $^{73}$ 76-78 Correlation with $H$ pylori status and intestinal metaplasia in other regions of the stomach is lacking; however, two studies reported to date have found a positive 
Table 2 Carditis, associations, and prevalence of intestinal metaplasia

\begin{tabular}{llll}
\hline Study & $\begin{array}{l}\text { Patients with intestinal } \\
\text { metaplasia (\%) }\end{array}$ & $\begin{array}{l}\text { Association with } \\
\text { H pylori }\end{array}$ & $\begin{array}{l}\text { Association with } \\
\text { GORD }\end{array}$ \\
\hline Goldblum and colleagues $^{72}$ & 9 & Yes & No \\
Morales and colleagues $^{76}$ & 23 & Yes & N/A \\
Hirota and colleagues $^{77}$ & 5.3 & Yes & N/A \\
Trudgill and colleagues $^{79}$ & 18 & No & No \\
Spechler and colleagues $^{75}$ & 18 & No & N/A \\
\hline
\end{tabular}

GORD, gastro-oesophageal reflux disease; N/A, information not given.

relation between cardia intestinal metaplasia, $H$ pylori infection, and diffuse multifocal intestinal metaplasia. Current available evidence suggests that the risk of developing intestinal metaplasia of the cardia is related to age $\mathrm{ag}^{79}$ and $H$ pylori status but not to GORD (table 2). Whether or not individuals on long term PPIs are at an increased risk, as reported for distal intestinal metaplasia, and whether this is a confounding factor is unknown. Assessment of the malignant potential of intestinal metaplasia of the cardia will require further study and its association with $H$ pylori infection confirmed as the results may change current management strategies.

\section{$H$ pylori eradication and GORD}

The indications for $H$ pylori eradication treatment have been broadened in recent years to include several conditions, not only peptic ulceration but also MALT lymphoma, early gastric cancer, and non-ulcer dyspepsia. ${ }^{81} 82$ The European consensus guidelines considered the role of eradication treatment in patients with GORD on long term treatment with PPIs. Recent publications have implicated concomitant PPI treatment and $H$ pylori infection with the accelerated development of atrophic gastritis and increased epithelial cell proliferation. ${ }^{83-86}$ Kuipers and colleagues ${ }^{83}$ studied $59 \mathrm{H}$ pylori positive subjects treated with either omeprazole or fundoplication for a mean follow up of five years. Thirty one per cent treated with a PPI versus only 5\% treated surgically developed atrophic gastritis. Atrophic gastritis is considered a risk factor for the subsequent development of gastric carcinoma. The situation is not clear cut as a recent study by Lundell et al, involving a randomised trial with a three year follow up, showed no increased risk of atrophic gastritis in $H$ pylori positive subjects taking PPIs compared with controls. ${ }^{86}$ The observation that PPIs are more effective in $H$ pylori positive individuals has also brought the policy of prescribing eradication treatment in this setting into question. ${ }^{87} 88$ Most reports do suggest that $H$ pylori infection and PPI treatment increases an individual's risk of developing gastric atrophy and as such the benefits of eradication treatment probably outweigh the possible drawbacks.

The successful eradication of $H$ pylori infection in cases of duodenal ulcer has been recently reported to be associated with the subsequent development of GORD. ${ }^{89}$ There are two possible explanations: either $H$ pylori infection is protective and eradication induces GORD, or successful treatment with possible alterations in lifestyle, unmasks pre-existing or a propensity for GORD. ${ }^{90}$ GORD has been reported to develop in 9-63\% of patients following successful $H$ pylori treatment. ${ }^{91}{ }^{92}$

However, up to $20 \%$ of patients with duodenal ulcer have pre-existing GORD on initial presentation..$^{93}$ With such a high incidence of concomitant disease and an associated increased risk of GORD development with age, it is unlikely that GORD arises de novo in patients with peptic ulcer simply as a result of $H$ pylori eradication and healing of corpus gastritis with an associated return to normal acid secretion..$^{94}$ More prospective long term follow up studies are again required to clarify this issue.

\section{Conclusion}

$H$ pylori infection does not seem to play a causal role in GORD, based on available epidemiological data. Despite this the effect of $H$ pylori infection on the efficacy of acid suppressants, the gold standard treatment for GORD, as well as the possible long term effects of both infection and GORD require practitioners to address the issue of whether or not to test for $H$ pylori in patients with GORD and if present whether eradication treatment should be prescribed. The Maastricht consensus report considered this issue and advised, on the basis of supportive evidence, that $H$ pylori treatment should be given to patients with GORD requiring long term acid suppression. The Canadian consensus report does not currently support this management strategy, as there is a need for additional supportive evidence to link $H$ pylori infection and the long term use of PPIs with the development of gastric atrophy.

Reports of de novo GORD development in patients after successful treatment of $H$ pylori associated duodenal ulceration also raise management issues. The possible development of GORD is unlikely to alter the strong indication for $H$ pylori eradication in patients with duodenal ulceration but may enable clinicians to inform patients prior to treatment or select an at risk group.

1 Weinbeck M, Barnett J. Epidemiology of reflux disease and reflux oesophagitis. Scand $\mathcal{F}$ Gastroenterol 1989;24(suppl 156):7-13.

2 Isoluri J, Laippala P. Prevalence of symptoms suggestive of gastrooesophageal reflux disease in the adult population. Ann Med 1995;27:67-70.

3 Locke GR, Talley NJ, Felt SL, et al. Prevalence and clinical spectrum of gastrooesophageal reflux disease: a population based study in Olmsted county Minnesota. Gastroenterology 1997;112:1448-56.

4 Mansi C, Savareno V, Mela GS, et al. Are clinical patterns of dyspepsia a valid guideline for appropriate use of dyspepsia a valid guideline for appropriate use of
endoscopy: a report on 2253 dyspeptic patients. Am $\mathcal{F}$ Gasendoscopy: a report on 2253

5 Kagevi I, Lafstedt S, Peerson LG, et al. Endoscopic findings and diagnosis in unselected dyspeptic patients at a primary health care center. Scand F Gastroenterol 1989;245:145-50.

6 Nebel OT, Fornes MF, Castell DO. Symptomatic gastrooesophageal reflux: incidence and pricipitating factors. $\mathrm{Am}$ f Dig Dis 1976;11:953-6.

7 Galmiche JP, Des Varannes B. Symptoms and disease severity in gastrooesophageal reflux disease. Scand $\mathcal{F}$ Gastroenterol 1994;29(suppl 201):62-8.

8 Spechler SJ. Epidemiology and natural history of gastrooesophageal reflux disease. Digestion 1992;311(suppl 1): 24-9.

9 Klauser GK, Schindlebeck NE, Miller-Lasner SA, et al. Symptoms in gastro-oesophageal reflux disease. Lancet 1990;335:205-8.

10 Dodds WJ, Dent J, Hogan WJ, et al. Mechanisms of gastrooesophageal reflux in patients with reflux oesophagitis. $N$ Engl F Med 1982;307:1547-52. 
11 Dent J, Holloway RH, Toouli J, et al. Mechanisms of lower oesophageal sphincter incompetence in patients with symptomati $1020-8$.

12 Kahrilas PJ, Dodds WJ, Hogan WJ, et al. Esophageal peristaltic dysfunction in peptic oesophagitis. Gastroenterology 1986;91:897-904

13 Ahtaridis G, Snape WJ, Cohen S, et al. Clinical and manometric findings in benign peptic strictures of the oesophagus. Dig Dis Sci 1979;24:858-61.

14 Mittal RK, Holloway RH, Penagini R, et al. Transient lower oesophageal sphincter relaxation. Gastroenterology 1995; 109:601-10.

15 Stanuci S, Bennet JR. Oesophageal acid clearing: one factor in the production of reflux oesophagitis. Gut 1974;15:8327.

16 Cunningham KM, Horowitz M, Riddell PS, et al. Relations among autonomic nerve dysfunction, oesophageal motility and gastric emptying in gastro-oesophageal reflux disease. Gut 1991;32:1436-40.

17 McCallum RW, Berkowitz DM, Lerner E. Gastric emptying in patients with gastro-oesophageal reflux. Gastroenterology in patients with gast

18 Orlando RC, Bryson JC, Powell DW. Mechanisms of H+ injury in rabbit oesophageal epithelium. Am $\mathcal{F}$ Physiol 1984; 246:G718-24.

19 Jankowski J, Murphy S, Coghill G, et al. Epidermal growth factors in the oesophagus. Gut 1992;33:439-43.

20 Safaie Shiraz IS, Den Besten L, Zike WL. Effect of bile salts on the ionic permeability of the oesophageal mucosa and their role in the production of oesophagitis. Gastroenterology 1975;68:728-33.

21 Collen MJ, Lewis JH, Benjamin SB. Gastric acid secretion in refractory gastro-oesophageal reflux disease. Gastroenterin refractory gastro-oesop

22 Cadiot G, Bruhat A, Rigaud D, et al. Multivariate analysis of pathophysiological factors in reflux oesophagitis. Gut 1997;40:167-74.

23 Miller LS, Vinayek R, Frucht H, et al. Reflux oesophagitis in patients with Zollinger Ellison syndrome. Gastroenterology 1990;98:1539-43.

24 Hunt $\mathrm{RH}$. The relationship between the control of $\mathrm{pH}$ and healing and symptom relief in gastrooesophageal reflux disease. Aliment Pharmacol Ther 1995;9(suppl 1):3-7.

25 Levi S, Beardshall K, Haddad G, et al. Campylobacter pylori and duodenal ulcers: the gastrin link. Lancet 1989;i: 1167-8.

26 Smith JTL, Pounder RE, Nwokolo CU, et al. Inappropriate hypergastrinaemia in asymptomatic healthy subjects in fected with Helicobacter pylori infection. Gut 1990;31 $522-5$

27 McColl KEL, Fullarton GM, Chittajulla R, et al. Plasma gastrin, day time intragastric $\mathrm{pH}$, and nocturnal acid output before and at 1 and 7 months after eradication of Helicobacter pylori in duodenal ulcer subjects. Scand $f$ Gastroenterol 1991;26:339-46.

28 Moss SF, Legon S, Bishop AE, et al. Effect of Helicobacter pylori on gastric somatostatin in duodenal ulcer disease. Lancet 1992;340:930-2.

29 Calam J, Beals ILP, Gibbons A, et al. Effects of abnormalities of gastrin and somatostatin in Helicobacter pylori
infection on acid secretion. In: Hunt RH, Tytgat GNJ, eds. infection on acid secretion. In: Hunt RH, Tytgat GNJ, eds. Helicobacter pylori: basic mechanisms to clinical
Kluwer Academic Publishers, 1996:108-21.

30 El-Omar E, Penman ID, Ardill JES, et al. Helicobacter pylori infection and abnormalities of acid secretion in patients with duodenal ulcer disease. Gastroenterology 1995;109:681-91

31 Chittajallu RS, Ardill JES, McColl KEL. The degree of hypergastrinaemia induced by Helicobacter pylori is the same in duodenal ulcer patients and healthy volunteers. Eur f Gastroenterol Hepatol 1992;4:49-53.

32 Harris AW, Gummett PA, Misiewicz JJ, et al. Eradication of Helicobacter pylori infection in patients with duodenal ulcer lowers basal and peak acid outputs to gastrin releasing peptide and pentagastrin. Gut 1996;38:663-8.

33 Boyd EJS. The prevalence of oesophagitis in patients with duodenal ulceration. Am f Gastroenterol 1996;91:1539-43.

34 El Omar EM, Oien K, El-Nujumi A, et al. Helicobacter pylori infection and chronic acid hyposecretion. Gastroenterology 1997;113:15-24.

35 Ohara S, Sikne H, Iijima K, et al. Gastric mucosal atrophy and prevalence of Helicobacter pylori in reflux oesophagitis of the elderly. Fpn ₹ Gastroenterol 1996;93:235-9.

36 Sekiguchi T, Shirota T, Harikoshi T, et al. Helicobacter pylori infection and severity of reflux oesophagitis [abpylori infection and severity of reflux
stract]. Gastroenterology 1996;110:A755.

37 Minota A, Mokshsgunddam S, Gallo SH, et al. Alteration in upper gastrointestinal motility in Helicobacter pylori positive non-ulcer dyspepsia. Am $\mathcal{F}$ Gastroenterol 1994;89:1797800 .

38 Barnett J, Behler EM, Appleman HD, et al. Campylobacter pylori is not associated with gastroparesis. Dig Dis Sci 1989;34:1677-80.

39 Scott AM, Kellow JE, Shuter B, et al. Intragastric distribution and gastric emptying of solids and liquids in functional dyspepsia, lack of influence of symptom subgroups and Helicobacter pylori associated gastritis. Dig Dis Sci 1993;38:2247-54.

40 Tucci A, Corinaldesi R, Stranghellini V. Helicobacter pylori infection and gastric function in patients with chronic idiopathic dyspepsia. Gastroenterology 1992;103:768-74.
41 Fink SM, Barwick KW, De Tuca V, et al. The association of histological gastritis with gastrooesophageal reflux and delayed gastric emptying. F Clin Gastroenterol 1984;6:3019.

42 Testoni PA, Bannolo F, Masci E, et al. Different interdigestive antroduodenal motility patterns in chronic antral gastritis with or without Helicobacter pylori infection. Dig Dis Sci 1993;38:2255-61.

43 Vicari J, Falk GW, Richter JE. Helicobacter pylori and acid peptic disorders of the oesophagus: is it conceivable? $\mathrm{Am} \mathcal{F}$ Gastroenterol 1997;92:1097-102.

44 Lee JM, O'Morain C. Different management for Helicobacter pylori positive and negative patients with gastrooesophageal reflux disease? Gut 1998;43(suppl 1):S14-20.

45 O'Connor HJ, Cunnane K. Helicobacter pylori and gastrooesophageal reflux disease- a prospective study. Irish $f$ Med Sci 1994;163:369-73.

46 Borkent MV, Beker JA. Treatment of ulcerative reflux oesophagitis with colloidal bismuth subcitrate in combination with cimetidine. Gut 1989;29:385-9.

47 Walker SJ, Birch PJ, Stewart M, et al. Campylobacter pylori in the oesophagus, stomach and duodenum. Gut 1989;30: 1338-44.

48 Cheng EH, Bermanski P, Silversmith M, et al. Prevalence of Campylobacter pylori in oesophagitis, gastritis and duodenal disease. Arch Intern Med 1989;149:1373-5.

49 Newton M, Bryan R, Burnham WR, et al. Evaluation of Helicobacter pylori in reflux oesophagitis and Barrett's oesophagus. Gut 1997;40:9-13.

50 Befrits R, Grandstrom M, Rylander M, et al. Helicobacter pylori in 205 consecutive endoscopy patients. Scand f Infect Dis 1993;25:185-91.

51 Liston R, Pitt MA, Banerjee AK. Reflux oesophagitis and Helicobacter pylori infection in elderly patients. Postgrad Med f 1996;72:221-3.

52 Werdmuller BFM, Loffeld RJLF. Helicobacter pylori infection has no role in the pathogenesis of reflux oesophagitis. Dig Dis Sci 1997;42:103-5.

53 Vicari JJ, Peek RM, Falk GW, et al. The seroprevalence of cag A-positive Helicobacter pylori strains in the spectrum of gastro-oesophageal reflux disease. Gastroenterology 1998; 115:50-7.

54 Haruma K, Mihara M, Kawaguchi $\mathrm{H}$, et al. Low prevalence of Helicobacter pylori infection in patients with reflux oesophagitis [abstract]. Gastroenterology 1996;110:A130.

55 Sehiguchi T, Shirota T, Horikoshi T, et al. Helicobacter pylori infection and severity of reflux oesophagitis [abpylori infection and severity of reflux
stract]. Gastroenterology 1996;110:A755.

56 Grebenev AL. Helicobacter pylori (Hp) and reflux oesophagitis [abstract]. Am $\mathcal{F}$ Gastroenterol 1994;89:A1372.

57 Cargill G, Atlan P, Tudor D, et al. Association of Helicobacter pylori and reflux oesophagitis in symptomatic children [abstract]. Gastroenterology 1994;106:A59.

58 Chow WH, Blaser MJ, Blot WJ, et al. An inverse relation between cag A+ strains of Helicobacter pylori infection and risk of oesophageal and gastric cardia carcinoma. Cancer Res 1998;58:588-90.

59 Grimley CE, Loft DE, Morris AG, et al. Virulent Helicobacter pylori in patients with gastric and oesophageal adenocarcinoma [abstract]. Gastroenterology 1997;112: A571.

60 Crabtree JE, Taylor JD, Wyatt JI, et al. Mucosal IgA recognition of Helicobacter pylori $120 \mathrm{kDa}$ protein, peptic ulceration, and gastric pathology. Lancet 1991;338:332-5.

61 Feldman M, Cryer B, McArthur KE, et al. Relationship between the severity of $\mathrm{H}$. pylori $(\mathrm{Hp})$ gastritis and gastric acid-pepsin secretion in man [abstract]. Gastroenterology 1996;110:A106.

62 Kuipers EJ, Perez-Perez GI, Meuwissen GM, et al. Helicobacter pylori and atrophic gastritis: importance of the cagA status. $\mathcal{F}$ Natl Cancer Inst 1995;87:1777-80.

63 Bercik P, Verdu EF, Armstrong D, et al. H. pylori related increase in omeprazole effect is associated with ammonia

production [abstract]. Gastroenterology 1996;110:A64.
64 Cover TL, Glupczynski Y, Lage AP, et al. Serologic Cover TL, Glupczynski Y, Lage AP, et al. Serologic
detection of infection with cagA + Helicobacter pylori strains. F Clin Microbiol 1995;33:1496-500.

65 Molloy RM, Sonnenberg A. Relation between gastric cancer and previous peptic ulcer disease. Gut 1997;40:247-52.

66 Talley NJ, Cameron A, Shorter R, et al. Campylobacter pylori and Barrett's esophagus. Mayo Clin Proc 1988;63: $117-80$.

67 Abbas Z, Hussainy AS, Farhat I, et al. Barrett's oesophagus and Helicobacter pylori. I Gastroenterol Hepatol 1995;10: 331-3.

68 Henihan RDJ, Stuart RC, Gorey TF, et al. Barrett's oesophagus and the presence of Helicobacter pylori. Am $\mathcal{f}$ Gastroenterol 1998;93:1-5.

69 Oberg S, Peters JH, DeMeester TR, et al. Inflammation and specialised intestinal metaplasia of the cardia mucosa is a manifestation of gastroesophageal reflux disease. Ann Surg 1997;226:522-32.

70 Genta RM, Huberman RM, Graham DY, et al. The gastric cardia in Helicobacter pylori infection. Hum Pathol 1994;25:915-19.

71 Spechler SJ, Wang HH, Chen YY, et al. GERD versus $\mathrm{H}$. pylori as potential causes of inflammation in the gastric cardia [abstract]. Gastroenterology 1997;112:A297.

72 Goldblum JR, Vicari JJ, Falk GW, et al. Inflammation and intestinal metaplasia of the gastric cardia: the role of gastroesophageal reflux and H. pylori infection. Gastroenterology 1998;114:633-9. 
73 Clarke GWB, Smyrk TC, Burdiles P, et al. Is Barretts metaplasia the source of adenocarcinoma of the cardia? Arch plasia the source of ad
Surg 1994;129:609-14.

74 Cameron AJ, Lomboy CT, Pera M, et al. Adenocarcinoma of the oesophagogastric junction and Barrett's oesophagus. Gastroenterology 1995;109:1541-6.

75 Spechler SJ, Wang HH, Chen YY, et al. Inflammation of the gastric cardia and $\mathrm{H}$. pylori infection are not risk factors for intestinal metaplasia at the esophagogastric junction [abstract]. Gastroenterology 1997;112:A297.

76 Morales TG, Sampliner RE, Bhattacharyya A. Intestinal metaplasia of the gastric cardia. Am $\mathcal{f}$ Gastroenterol 1997;92:414-18.

77 Hirota WK, Loughney TM, Lazas DJ, et al. Is Helicobacter pylori associated with specialised intestinal metaplasia of the oesophagus or stomach? A prospective study of 889 patients [abstract]. Gastroenterology 1997;112:A149.

78 Cameron AJ, Kamath PS, Carpenter HA, et al. Prevalence of Barrett's oesophagus and intestinal metaplasia at the of Barrett's oesophagus and intestinal metaplasia at the 1997; 112:A8.

79 Trudgill NJ, Suvarna SK, Kapur KC, et al. Intestinal metaplasia at the squamocolumnar junction in patient attending for diagnes

80 The European Helicobacter pylori Study Group. Current European concepts in the management of Helicobacter pylori infection. The Maastricht consensus report. Gut 1997;41:8-13.

81 Hunt R, Thompson ABR. Canadian Helicobacter pylori consensus conference. Can f Gastroenterol 1998;12:31-41.

82 Kuipers EJ, Uyterlinde AM, Pena AS, et al. Incidence of Helicobacter pylori associated corpus gastritis during acid suppression therapy: implications for long term safety. $A m$ f Gastroenterol 1995;90:1401-6.

83 Kuipers EJ, Lundell L, Klinkenberg-Knoll EC, et al. Atrophic gastritis and Helicobacter pylori infection in patients with reflux oesophagitis treated with omeprazole or fundoplication. N Engl f Med 1996;334:1018-22.

84 Lamberts R, Creutzfeldt W, Struber HG, et al. Long term omeprazole therapy in peptic ulcer disease: gastrin, endocrine cell growth and gastritis. Gastroenterology 1993; 104:1356-70.
85 Berstad AE, Hatlebakk FG, Maartmann-Moe H, et al. Helicobacter pylori, gastritis and epithelial cell proliferation in patients with reflux oesophagitis after treatment with omeprazole. Gut 1997;41:735-9.

86 Lundell L, Havu N, Andersson A, et al. Gastric atrophy development and acid supression therapy revisited. Result of a randomised clinical study with long term follow up [abstract]. Gastroenterology 1997;112:A28

87 Verdu EF, Armstrong D, Fraser R, et al. Effect of Helicobacter pylori status on intra-gastric $\mathrm{pH}$ during treatment with omeprazole. Gut 1995;37:743-8.

88 Labenz J, Tillenburg B, Peitz U, et al. Helicobacter pylori augments the $\mathrm{pH}$ increasing effect of omeprazole in patients with duodenal ulcer. Gastroenterology 1996;110: patients

89 Hirschl AM, Schulze K, Hentsche E, et al. Serological, microbiological and clinical results of a 43 months follow-up after successful eradication of $\mathrm{H}$. pylori in duodenal ulcer disease. Am f Gastroenterol 1994;89:1374.

90 Labenz J, Blum AL, Bayerdorffer E, et al. Curing Helicobacter pylori infection in patients with duodenal ulcer may provoke reflux oesophagitis [abstract]. Gastroenterology 1997;112:A282.

91 Sacca N, DeMichii A, Rodino S, et al. Reflux oesophagitis: a complication of Helicobacter pylori eradication therapy. Gut 1996;39(suppl 3):A35.

92 Di Mario F, Dal Bó N, Saladin S, et al. The appearance of GORD in patients with duodenal ulcer after eradication of Helicobacter pylori $(\mathrm{Hp})$ infection: A 4-year prospective study. Gut 1998;43(suppl 2):A95

93 O'Connor HJ, McGee C, Mehan N, et al. Prevalence of astro-oesophageal reflux disease (GORD) in $\mathrm{H}$. pylori positive peptic ulcer disease and the short term effects of eradication therapy [abstract]. Irish 7 Med Sci 1997; 116(suppl 6):19.

94 Isolauri J, Laippala P. Prevalence of symptoms suggestive of gastro-oesophageal reflux disease in an adult population. Ann Med 1995;27:67-70.

95 Chang CS, Poon SK, Lien HC, et al. The incidence of reflux oesophagitis among Chinese. Am $\mathcal{F}$ Gastroenterol 1997;92: 668-71. 